\title{
СТАН ЗАТУЛЬНОЇ ФУНКЦІЇ ПАХВИННОГО КАНАЛУ ПІСЛЯ АЛОПЛАСТИКИ ПАХВИННОЇ ГРИЖІ
}

\author{
І. В. Бабій, Л. П. Брико, В. В. Власов \\ Вінницький національний медичний університет імені М. І. Пирогова, \\ Хмельницька обласна лікарня

\section{STATE OF OBTURATIVE FUNCTION OF INGUINAL CHANNEL AFTER PERFORMANCE OF THE INGUINAL HERNIA ALLOPLASTY}

\author{
I. V. Babiy, L. P. Bryko, V. V. Vlasov \\ Vinnytsya National Medical University named after M. I. Pyrogov, \\ Khmelnytskyi Regional Hospital
}

\begin{abstract}
Реферат
За даними ультразвукового дослідження (УЗД) проаналізовані зміни у пахвинному каналі у 30 здорових чоловіків і 39 хворих, у яких здійснено алопластику (за методом Lichtenstein - у 18, черезпахвинну передочеревинну алопластику грижового дефректу - TIPP у модифікації авторів - у 21) з приводу пахвинної грижі при напруженні (підняття нижніх кінцівок на $15^{\circ}$ ). Досліджено швидкість кровотоку в артеріях яєчка після алопластики. Доведено, що при напруженні м'язів живота достовірно збільшується відстань між передньою і задньою стінками пахвинного каналу; порушення швидкості кровотоку в артеріях яєчка після алопластики не виявлене.

Ключові слова: пахвинна грижа; алопластика; ультразвукове дослідження; артерії яєчка.

Abstract

The changes in inguinal channel in 30 healthy men and 39 patients, in whom alloplasty (in accordance to Lichtenstein procedure - in 18, transinguinal preperitoneal alloplasty of hernial defect - TIPP in the author's modification - in 21) was performed for inguinal hernia, occurring in abdominal tension (while the lower extremities raising by $15^{\circ}$ ) were analyzed in accordance to the ultrasonographic data obtained. Velocity of the blood flow in the testis arteries after alloplasty was investigated. There was trustworthily proved, that while the abdominal muscles tension occurs the distance between anterior and posterior walls of inguinal channel enhances; the disorder of the blood flow velocity in the testis arteries after performance of alloplasty was not revealed.

Keywords: inguinal hernia; alloplasty; ultrasonographic investigation; arteries of testis.
\end{abstract}

Пахвинна грижа виникає у 5\% дорослих чоловіків, у 5 - 15\% - операцію виконують у невідкладному порядку. Сучасне хірургічне лікування з приводу пахвинної грижі передбачає використання ненатяжних методів пластики пахвинного каналу 3 застосуванням сітчастих імплантатів [1]. Хірургічне лікування пахвинної грижі у 6,65\% чоловіків є основною причиною безпліддя, при цьому якість сперми значно погіршується [2]. В експерименті доведено, що сітка, крім прямого тиску на сім'яний канатик, звужує його просвіт шляхом стискання, зменшує артеріальне кровопостачання яєчка, отже, впливає на сперматогенез [3, 4]. Алопластика 3 приводу пахвинної грижі істотно змінюе кровоток у яєчку за даними допплерографії в ранньому післяопераційному періоді, проте, суттєво не впливає на кількість сперматозоїдів або швидкість ïx руху [5]. Інші дослідники вважа- ють, що алопластика не справляє негативний вплив на кровоток в яєчку [6]. В літературі є повідомлення, що визначення інтратестикулярного кровотоку може бути інформативним прогностичним критерієм сперматогенезу [7].

Мета дослідження: проаналізувати вплив алопластики грижового дефекту на кровоток в яєчку та затульну функцію пахвинного каналу після операції.

\section{МАТЕРІАЛИ I МЕТОДИ ДОСЛІДЖЕННЯ}

У дослідження включені 39 чоловіків віком від 36 до 87 років, у середньому $(58,6 \pm 10,4)$ року, у яких виявлено пахвинну грижу. Хворі розподілені на дві групи залежно від методу пластики грижового дефекту. У 18 хворих (1-ша група) застосована операція Lichtenstein, у 21 (2-га група) - ТІРР в модифікації авторів. Розміри грижового дефекту визна- чали за класифікацією EHS: pM2 - у 3 хворих, pM3 - у 3, pL2 - у 13, pL3 у $16, \mathrm{pC} 3-\mathrm{y} 4$.

УЗД пахвинної ділянки здійснювали з використання апарата Toshiba Aplio 500 у положенні пацієнтів лежачи на спині. Під час дослідження ділянки пахвинного трикутника (пахвинного каналу) на нижній межі лобкової та пахвинної ділянок чітко візуалізується лобковий горбок у вигляді гіперехогенної напівкруглої структури. Він є сталим кістковим орієнтиром. Рухаючи датчик в бік і паралельно пахвинній зв'язці, знаходимо під нею гіпоехогенне овально-округле утворення - стегнову вену. Поруч з нею ззовні визначається такої ж самої ехогенності пульсуюче утворення округлої форми стегнова артерія. Ці утворення є серединним ультразвуковим орієнтиром пахвинного фасціального вузла. Над стегновим судинним пучком визначаються невеликих розмірів гі- 
поехогенні утворення - нижні надчеревні судини $[8,9]$.

Після алопластики грижового дефекту проводили УЗД пахвинного каналу. Для вивчення затульної функції пахвинного каналу вимірювали товщину прямого, внутрішнього косого і поперечного м'язів живота, висоту пахвинного проміжку у спокою та при напруженні (піднімання верхніх кінцівок на $15^{\circ}$ ) у хворих, яким виконана алопластика грижового дефекту, через 1 міс після операції.

У 30 здорових чоловіків за даними УЗД вивчені зміни в ділянці пахвинного каналу у спокою і при напруженні (контрольна група).

Датчик PLT-704SBT (діапазон частот 4,8 - 11,0 МГц) розташовували на шкірі мошонки над яєчком. Сканування проводили у реальному часі у поздовжньому і поперечному напрямках для встановлення змін тестикулярного кровотоку на боці грижі і на інтактному боці. Інтратестикулярний кровоток вивчений у 30 хворих, оперованих 3 приводу пахвинної грижі. Дані, отримані на інтактному боці, приймали за контроль. Тестикулярний кровоток оцінювали за піковою систолічною швидкістю, яку визначали в середині і на обох полюсах яєчка в ранньому післяопераційному періоді (на 4 - 5-ту добу).

Хворі обстежені 3 використанням клініко-лабораторних методів (огляд, загальноклінічні, біохімічні дослідження, УЗД, флюорографія, ЕГДФС).

\section{РЕЗУЛЬТАТИ}

Однобічна пахвинна грижа справа виявлена у 19 хворих, зліва - у 20; пряма (медіальна) грижа - у 6; середні та великі грижові дефекти виявляли з однаковою частотою. Коса (латеральна) пахвинна грижа відзначена у 33 хворих, великі грижові дефекти - у 18; комбінована (панталонна) грижа великих розмірів у 4, малих грижових дефектів не було. У хворих 1-ї групи не спостерігали медіальну і комбіновану грижу, латеральна грижа середнього розміру виявлена у 10, великого - у 8 . у 2-й групі латеральна грижа виявлена у 12 хворих, комбінована - у 4. у 2,5 разу частіше відзначали великий грижовий дефект (у 15 хворих), ніж середній (у 6).

За даними УЗД у 30 здорових чоловіків вивчені зміни в м'язах пахвинної ділянки живота у спокою і при напруженні (табл. 1). Отримані результати свідчили, що в осіб без пахвинної грижі при напруженні достовірно збільшується товщина прямого, внутрішнього косого і поперечного м'язів живота. Поряд 3 цим, достовірно збільшується відстань між апоневрозом зовнішнього косого м'яза живота і поперечною фасцією пахвинного проміжку (товщина пахвинного каналу) (р < 0,001).
Висота пахвинного проміжку при напруженні зменшується, проте, недостовірно. Через 1 міс після алопластики за даними УЗД простежується сітковий імплантат позаду сім'яного канатика незалежно від методу виконання пластики. Поперечну фасцію не завжди вдається візуалізувати.

Аналогічні дослідження проведені у 39 пацієнтів після алопластики ( мабл. 2). При напруженні, незалежно від виду алопластики, відзначали достовірне збільшення товщини прямого, внутрішнього косого і поперечного м'язів живота, товщини пахвинного каналу. Висота пахвинного проміжку зменшувалась. Тобто, зміни у пахвинній ділянці у здорових осіб та у пацієнтів після алопластики у спокою і при навантаженні зіставні.

Під час напруження товщина пахвинного каналу достовірно збільшується, це свідчить, що після операції затульний механізм пахвинного каналу не порушується, що запобігає можливому порушенню кровотоку в сім'яному канатику і яєчку.

Пікова систолічна швидкість кровотоку в артерії яєчка вивчена у 30 хворих $з$ пахвинною грижею, в тому числі з однобічною справа - у 16, зліва - у 14; прямою - у 6; косою (латеральною) - у 22; грижові дефекти великих розмірів виявлені у 14 .

Стан кровотоку в яєчку вивчений у пацієнтів на інтактному боці (кон-

Таблиця 1. Показники пахвинного каналу у здорових дорослих людей у спокою і при напруженні

\begin{tabular}{|l|c|c|c|}
\hline \multicolumn{1}{|c|}{ Показник } & \multirow{2}{*}{ Кількість хворих } & \multicolumn{2}{c|}{ Величина показника $(\overline{\mathrm{x}} \pm \mathrm{m})$} \\
\cline { 3 - 4 } & & у спокою & при напруженні \\
\hline Товщина прямого м'яза живота над лобком, мм & 30 & $13,22 \pm 2,11$ & $14,88 \pm 1,79 *$ \\
\hline $\begin{array}{l}\text { Товщина внутрішнього косого і поперечного м'язів } \\
\text { живота на 1 см вище пахвинного серпа, мм }\end{array}$ & 30 & $11,52 \pm 1,75$ & $12,58 \pm 2,00 *$ \\
\hline Товщина пахвинного каналу, мм & 30 & $11,47 \pm 1,64$ & $13,38 \pm 1,62^{*}$ \\
\hline Висота пахвинного проміжку, мм & 30 & $15,62 \pm 3,59$ & $15,35 \pm 4,44 *$ \\
\hline
\end{tabular}

Примітка. $\quad$ * - різниця показників достовірна порівняно з такими у спокою $(p<0,05)$. Те ж у табл. 2.

Таблиця 2. Показники пахвинного каналу після його алопластики у спокою і при напруженні

\begin{tabular}{|c|c|c|c|c|}
\hline \multirow{3}{*}{ Показник } & \multicolumn{4}{|c|}{ Величина показника в групах $(\bar{x} \pm \mathrm{m})$} \\
\hline & \multicolumn{2}{|c|}{$1-и ̆(n=18)$} & \multicolumn{2}{|c|}{$2-\breve{~}(n=21)$} \\
\hline & у спокою & при напруженні & у спокою & при напруженні \\
\hline $\begin{array}{l}\text { Товщина прямого м'яза живота над } \\
\text { лобком, мм }\end{array}$ & $13,2 \pm 1,22$ & $14,43 \pm 1,63^{*}$ & $12,98 \pm 1,41$ & $14,44 \pm 1,77^{*}$ \\
\hline $\begin{array}{l}\text { Товщина внутрішнього косого і } \\
\text { поперечного м'язів живота на } 1 \text { см вище } \\
\text { пахвинного серпа, мм }\end{array}$ & $11,65 \pm 2,32$ & $13,31 \pm 2,44^{*}$ & $10,86 \pm 1,53$ & $12,31 \pm 1,87^{*}$ \\
\hline Товщина пахвинного каналу, мм & $12,58 \pm 1,25$ & $13,95 \pm 1,23^{*}$ & $12,67 \pm 1,02$ & $13,66 \pm 1,45^{*}$ \\
\hline Висота пахвинного каналу, мм & $19,32 \pm 6,32$ & $16,94 \pm 3,69^{*}$ & $20,12 \pm 7,5$ & $18,26 \pm 5,84$ \\
\hline
\end{tabular}


трольна група) і на боці, де здійснено алопластику пахвинного каналу, у спокою і при напруженні.

Пікова систолічна швидкість в артерії яєчка становила: у контрольній групі у спокою- $(5,68 \pm 2,1) \mathrm{cm} / \mathrm{c}$, при напруженні - $(5,49 \pm 1,5)$ см/с; у хворих 1-ї групи - відповідно $(5,1 \pm$ $1,43)$ i $(5,25 \pm 1,2) \mathrm{cm} / \mathrm{c} ; 2-\ddot{1}$ групи $(5,28 \pm 1,3)$ i $(5,35 \pm 1,2) \mathrm{cm} / \mathrm{c}$.

Отримані дані свідчать, що на інтактному боці і після алопластики при напруженні пікова систолічна

\section{REFERENCES}

1. Hentati H, Dougaz W, Dziri C. Mesh repair versus non-mesh repair for strangulated inguinal hernia: Systematic review with meta-analysis. World J Surg. 2014;38(11):2784-90.

2. Yavetz $H$, Harash $B$, Yogev $L$, et al. Fertility of men following inguinal hernia repair. Andrologia. 1991;23(6):443-6.

3. Peiper $C$, Junge $K$, Klinge $U$, et al. Is there a risk of infertility after inguinal mesh repair? Experimental studies in the pig and the rabbit. Hernia. 2006;10(1):7-12.

4. Uzzo RG, Lemack GE, Morrissey KP, Goldstein M. The effects of mesh bioprosthesis on the spermatic cord structures: A preliminary report in a canine model. J Urol. 1999;161(4):1344-9.

5. Sucullu I, Filiz Al, Sen B, et al. The effects of inguinal hernia repair on testicular function in young adults: A prospective randomized study. Hernia. 2010;14(2):165-9.

6. Ramadan SU, Gokharman D, Tuncbilek I, et al. Does the presence of a mesh have an effect on the testicular blood flow after surgical repair of indirect inguinal hernia? J Clin Ultrasound. 2009;37(2):78-81.
7. Pinggera GM, Mitterberger M, Bartsch G, et al. Assessment of the intratesticular resistive index by colour Doppler ultrasonography measurements as a predictor of spermatogenesis. BJU Int. 2008;101(6):722-6.

8. Hreshylo OO, Babii IV, Mykytiuk SR, Bryko LP. Ultrazvukove doslidzhennia pakhvynnoho kanalu u zdorovykh liudei. In: XIV mizhnarodnyi medychnyi konhres studentiv ta molodykh vchenykh, 13 - 15 kvitnia 2010. Vinnitsya, 2010::55.

9. Hreshylo OO, Babii IV, Mykytiuk SR, Bryko LP. Ultrazvukove doslidzhennia pakhvynnoho kanalu u zdorovykh liudei i khvorykh na pakhvynnu hryzhu. In: Materialy I Naukovoi konferentsii molodykh vchenykh z mizhnarodnoiu uchastiu. VNMU im. M. I. Pyrohova. Vinnytsia; 2010:69. 